\title{
KELAYAKAN ASPEK MEDIA DAN BAHASA DALAM PENGEMBANGAN BUKU AJAR DAN MULTIMEDIA INTERAKTIF BIOLOGI SEL
}

\author{
Dini Safitri ${ }^{1}$, Tri Asih Wahyu Hartati ${ }^{2}$ \\ ${ }^{1,2)}$ Pendidikan Jasmani, Kesehatan, dan Rekreasi IKIP Budi Utomo Malang \\ Jalan Simpang Arjuno 14B Klojen, Kota Malang, Jawa Timur, Indonesia \\ email: ${ }^{1}$ triasihbioum2012@gmail.com, ${ }^{2}$ diniearchie@gmail.com \\ Diterima 2 Agustus 2016, Disetujui 28 September 2016
}

\begin{abstract}
Instructional materials are supporting the success of learning. The purpose is the development of teaching materials to help facilitate the learning process so that learners drafting special requirements that must be met. One of the compulsory subjects in biology education courses are of Cell Biology, and based on the needs analysis, multimedia-assisted teaching materials is very required This research aims to develop products Cell Biology course textbook aided interactive multimedia using the 4D model viable aspect kegrafikan (media) and language. The 4D model consists of stages define, design, develop, and disseminate. The development phase is limited to stages develop. This research generates results media and language as validation data. The tests showed that the textbook and interactive multimedia eligible for use in the real learning of Biology Cell course.Validator also put forward suggestions for the improvement of some parts of teaching materials.
\end{abstract}

Keywords: $\quad$ textbook, interactive multimedia, biology, cell biology

\section{PENDAHULUAN}

Perkembangan IPTEK yang semakin pesat mendorong pendidikan tinggi untuk selalu mengadakan pemutakhiran kurikulum yang akan berimbas pada perubahan komponen isi matakuliah dan bahan ajar yang digunakan. Bahan ajar merupakan penunjang keberhasilan belajar. Bahan ajar yang bervariasi dan lengkap dapat mendukung proses pembelajaran dalam rangka mencapai tujuan yang diharapkan. Bahan ajar yang digunakan umumnya bervariasi sesuai dengan materi dan kondisi pembelajaran yang akan dilaksanakan.

Tujuan pengembangan bahan ajar adalah membantu mempermudah proses belajar peserta didik sehingga penyusunannya memerlukan persyaratan khusus yang harus dipenuhi. Syarat-syarat khusus tersebut antara lain: (1) memberikan orientasi terhadap teori, penalaran teori, dan cara-cara penerapan teori dalam praktik, (2) terdapat latihan terhadap pemakaian teori dan aplikasinya, (3) bahan ajar memberikan umpan balik mengenai latihan tersebut, (4) menyesuaikan informasi dan tugas dengan tingkat perkembangan mahasiswa, (5) membangkitkan minat mahasiswa, (6) menjelaskan sasaran belajar kepada mahasiswa, (7) meningkatkan motivasi mahasiswa, serta (8) menunjukkan sumber informasi yang lain (Mbulu, dkk., 2004).

Salah satu matakuliah wajib dalam program studi pendidikan biologi adalah biologi sel. Pada penelitian sebelumnya, telah dikembangkan buku ajar cetak yang mencakup uraian materi, latihan, evaluasi, dan refleksi diri. Berdasarkan hasil uji coba kepada responden mahasiswa pendidikan biologi Universitas Nusantara PGRI Kediri pada tahun 2014, diperoleh data kuantitatif berupa persentase hasil uji perorangan dan kelompok kecil sebesar 81,548\% dan 79,950\%. Berdasarkan perhitungan tersebut, keseluruhan buku ajar memiliki kategori layak dengan predikat bagus. Menurut responden, buku ajar mata kuliah Biologi Sel yang telah dikembangkan memiliki beberapa kelemahan yaitu tidak 
adanya dukungan bahan ajar multimedia untuk bahan ajar cetak Biologi Sel. Materi dalam Biologi Sel bersifat abstrak dan tidak ada kegiatan laboratorium. Lebih lanjut dikatakan bahwa penyusunan bahan ajar yang disusun secara manual belum mampu mengatasi permasalahan belajar yang dihadapi peserta didik. Solusi yang dapat ditempuh untuk memperbaiki keadaan tersebut adalah merevisi buku ajar cetak yang sudah dikembangkan secara menyeluruh dan menyusunnya kembali dalam bentuk bahan ajar multimedia interaktif sebagai pendamping buku ajar cetak. Hasil penyebaran angket analisis kebutuhan yang telah dilakukan ke mahasiswa Program Studi Pendidikan Biologi IKIP Budi Utomo Malang yang telah menempuh matakuliah Biologi Sel menunjukkan bahwa permasalahan yang dihadapi selama menempuh matakuliah Biologi Sel antara lain kurangnya sarana dan prasarana $(19,04 \%)$, kurang memahami materi $(42,85 \%)$, kurangnya kegiatan praktikum $(33,33 \%)$, dan keterbatasan referensi yang dimiliki mahasiswa (4,76\%). Bahan ajar yang digunakan mahasiswa selama mengikuti perkuliahan antara lain makalah, power point, buku, dan sumber referensi dari internet. Hasil pengisian angket perihal pemahaman mahasiswa mengenai bahan ajar multimedia menunjukkan bahwa sebagian besar mahasiswa $(73,33 \%)$ mengetahui tentang bahan ajar multimedia interaktif. Sebagian besar mahasiswa $(73,33 \%)$ menyatakan bahwa penggunaan bahan ajar multimedia interaktif sangat diperlukan untuk menunjuang kegiatan perkuliahan Biologi Sel.

Konsep-konsep dalam Biologi Sel dapat dipahami secara menyeluruh apabila disertai dengan visualisasi beberapa konsep. Bahan ajar multimedia interaktif bertujuan untuk memperjelas dan mempermudah penyajian pesan agar tidak terlalu bersifat verbal; mengatasi keterbatasan waktu, ruang, dan daya indera; meningkatkan motivasi belajar untuk menguasai materi perkuliahan secara utuh; serta mengembangkan kemampuan mahasiswa dalam berinteraksi langsung dengan lingkungan dan sumber belajar yang berbasis TI (Program P3AI, 2007).

Dalam hirarki pengembangan media pembelajaran, dalam hal ini buku ajar dan multimedia, tahap validasi oleh pakar menjadi satu tahap yang penting. Pada tahapan develop dalam model pengembangan 4D (Thiagarajan, 1974), bahan ajar yang telah dikembangkan harus melalui tahap validasi oleh pakar atau ahli di bidang bahan ajar tersebut. Beberapa aspek dalam bahan ajar yang harus divalidasi atau diuji kelayakannya diantaranya adalah aspek media dan bahasa. Penelitian ini bertujuan untuk menghasilkan buku ajar cetak dan multimedia interaktif yang layak ditinjau dari aspek kelayakan media dan bahasa.

\section{METODE}

Penelitian ini merupakan penelitian pengembangan yang menggunakan model pengembangan 4D yang dikemukakan oleh Thiagarajan (1974). Model pengembangan 4D memiliki 4 tahap yaitu define, design, develop, dan disseminate. Pada penelitian ini, tahapan model pengembangan dibatasi hingga tahap develop yaitu validasi oleh ahli bahasa dan media. Prosedur penelitian ini meliputi tahap define, design, dan develop. Pada tahap define, dilakukan analisis kebutuhan instruksional yang diperlukan untuk pengembangan buku ajar yang meliputi langkah-langkah: (1) menganalisis kompetensi dasar matakuliah biologi sel, (2) mengidentifikasi sarana prasarana dan permasalahan pembelajaran, (3) mengidentifikasi kelemahan dan kekurangan buku ajar cetak biologi sel yang telah dikembangkan, serta (4) melaksanakan penyebaran angket analisis kebutuhan ke mahasiswa Program Studi Pendidikan Biologi yang telah menempuh matakuliah Biologi Sel.

Tahap design dilakukan untuk menghasilkan draft awal buku ajar cetak 
edisi revisi dan multimedia interaktif untuk matakuliah Biologi Sel. Tahap ini dilakukan melalui langkah berikut. 1) Penyusunan tes acuan patokan. Tes acuan patokan digunakan untuk menilai substansi dan struktur bahan ajar yang akan dikembangkan. Hasilnya berupa lembar validasi dan lembar uji keterbacaan; 2) Pemilihan format buku ajar cetak dan multimedia interaktif disesuaikan dengan kriteria komponen buku ajar yang disesuaikan dengan analisis kebutuhan pada tahap define.

Tahap develop bertujuan untuk merevisi draft awal buku ajar cetak dan multimedia interaktif yang telah disusun pada tahap design. Revisi didasarkan oleh proses validasi yang dilakukan oleh ahli media (ahli bahan ajar), dan ahli bahasa. Validator masing-masing merupakan ahli di bidangnya dengan kualifikasi pendidikan minimal S3 dan berpengalaman minimal 5 tahun di bidangnya.

Instrumen yang digunakan dalam pengumpulan data antara lain: angket analisisi kebutuhan, lembar validasi bahan ajar oleh ahli media, dan lembar validasi bahan ajar oleh ahli bahasa. Pengumpulan data dilaksanakan antara bulan Februari hingga Juli 2016. Tahap-tahap pengumpulan data antara lain: penyebaran angket analisis kebutuhan ke mahasiswa Program Studi Pendidikan Biologi IKIP Budi Utomo yang Telah menempuh matakuliah Biologi Sel; analisis dokumen matakuliah (RPS); mengidentifikasi kelemahan buku ajar cetak Biologi Sel versi sebelumnya; penyusunan bahan ajar; serta proses validasi oleh ahli. Data yang telah dikumpulkan dianalisis menggunakan statistik deskriptif. Rumus yang digunakan yaitu.

$$
P=\frac{x}{x i} \times 100 \%
$$

Keterangan:

$\mathrm{P}=$ Persentase tiap kriteria

$\mathrm{x}=$ skor tiap kriteria

$\mathrm{xi}=$ skor maksimal tiap kriteria
Hasil yang diperoleh dari rumus di atas akan dirujuk ke kriteria kelayakan bahan ajar (Tabel 1) untuk mengetahui kelayakan produk bahan ajar.

Tabel 1. Kriteria Kelayakan Buku Ajar Cetak dan Multimedia Interaktif

\begin{tabular}{ll}
\hline Skala (\%) & Kriteria Kelayakan \\
\hline $85-100$ & layak dengan predikat sangat bagus \\
$65-84$ & layak dengan predikat bagus \\
$45-64$ & layak dengan predikat cukup \\
$0-44$ & tidak layak \\
\hline
\end{tabular}

(Modifikasi: Pusat Perbukuan dan

Kurikulum, 2008)

\section{HASIL DAN PEMBAHASAN}

\section{Deskripsi Desain Awal Bahan Ajar}

Hasil pengembangan bahan ajar berupa dua komponen yaitu buku ajar cetak dan multimedia interaktif. Komponen buku ajar cetak terdiri atas bagian pendahuluan, isi, dan penutup. Bagian pendahuluan terdiri atas cover, halaman sampul, prakata, daftar isi, kompetensi dasar, dan petunjuk penggunaan buku ajar. Bagian isi terdiri atas 9 bab, dan tiap bab berisi judul bab, tujuan, uraian materi, rangkuman, aktivitas mahasiswa, soal evaluasi, dan kolom refleksi diri. Per subbab diberikan halaman kosong untuk menuliskan intisari dari subbab tersebut. Bagian penutup terdiri atas indeks, glosarium, dan lampiranlampiran. Bagian lampiran berisi panduanpanduan untuk menganalisis struktur protein menggunakan aplikasi computer, mengakses dan menganalisis jurnal utinternasional. Bagian penutup ini bersifat melengkapi bagian isi dam diharapkan mempermudah mahasiswa dalam mempelajari bahan ajar.

Multimedia interaktif dikembangkan untuk mendukung buku ajar cetak. Multimedia interaktif yang dikembangkan adalah multimedia berbasis flash yang dibuat dengan aplikasi Macromedia Flash 8 dan dijalankan dengan aplikasi Macromedia Flash Player. Multimedia ini juga dapat 
diputar pada laptop atau computer dengan sistem operasi Windows sekalipun laptop atau computer tersebut tidak memiliki aplikasi Macromedia Flash 8 dan Macromedia Flash Player.

Multimedia interaktif yang dikembangkan terdiri atas 8 file berbasis flash sesuai dengan buku ajar cetak, namun untuk Bab Mitokondria dan Kloroplas dijadikan satu bagian multimedia dikarenakan pembahasan yang hampir sama. Multimedia interaktif dilengkapi dengan latar suara berupa musik instrumen klasik dan gambar ilustrasi yang mewakili bab yang dibahas. Warna latar yang digunakan dominan warna putih. Warna huruf dominan hitam dan untuk judul diberikan warna selain hitam. Komponenkomponen dalam tiap file multimedia interaktif terdiri atas halaman pembukaan, petunjuk penggunaan multimedia, visualisasi konsep, evaluasi berupa games pilihan ganda, dan halaman penutup (berisi identitas pengembang dan sumber pustaka).

\section{Hasil Validasi Ahli Terhadap Bahan Ajar}

Bahan ajar (buku ajar cetak dan multimedia interaktif) melalui proses validasi media dan bahasa yang melibatkan ahli media dan teknologi pembelajaran, serta ahli kebahasaan. Validasi dilakukan oleh validator ahli media dan validator aspek kebahasaan. Hasil penilaian masingmasing validator dihitung persentase masing-masing aspek validasi untuk mengetahui kelayakan per bagian bahan ajar, dan dihitung persentase keseluruhan untuk mengetahui kelayakan keseluruhan produk. Hasil perhitungan dikonsultasikan pada Tabel 2 untuk mengetahui kelayakan produk. Hasil perhitungan validasi ahli materi dan media tersaji dalam Tabel 2.
Tabel 2. Hasil Validasi Bahan Ajar oleh Ahli Media dan Bahasa

\begin{tabular}{|c|c|c|c|}
\hline $\begin{array}{c}\text { Bahan } \\
\text { Ajar }\end{array}$ & $\begin{array}{c}\text { Aspek } \\
\text { Validasi }\end{array}$ & $\begin{array}{c}\text { Hasil } \\
\text { Validasi }\end{array}$ & $\begin{array}{c}\text { Ketera- } \\
\text { ngan }\end{array}$ \\
\hline \multirow{2}{*}{$\begin{array}{l}\text { Buku } \\
\text { Ajar }\end{array}$} & Media & $77,34 \%$ & $\begin{array}{l}\text { Layak } \\
\text { dengan } \\
\text { predikat } \\
\text { bagus }\end{array}$ \\
\hline & Bahasa & $83,33 \%$ & $\begin{array}{l}\text { Layak } \\
\text { dengan } \\
\text { predikat } \\
\text { bagus }\end{array}$ \\
\hline \multirow{2}{*}{$\begin{array}{l}\text { Multi- } \\
\text { media } \\
\text { Interak- } \\
\text { tif }\end{array}$} & Media & $76,47 \%$ & $\begin{array}{l}\text { Layak } \\
\text { dengan } \\
\text { predikat } \\
\text { bagus }\end{array}$ \\
\hline & Bahasa & $75 \%$ & $\begin{array}{l}\text { Layak } \\
\text { dengan } \\
\text { predikat } \\
\text { bagus }\end{array}$ \\
\hline
\end{tabular}

Selain memberikan penilaian dalam bentuk angka, validator juga memberikan penilaian dalam bentuk saran-saran untuk perbaikan buku ajar. Saran-saran tersebut terangkum dalam Tabel 3.

Tabel 3. Saran-saran Perbaikan Bahan Ajar oleh Validator

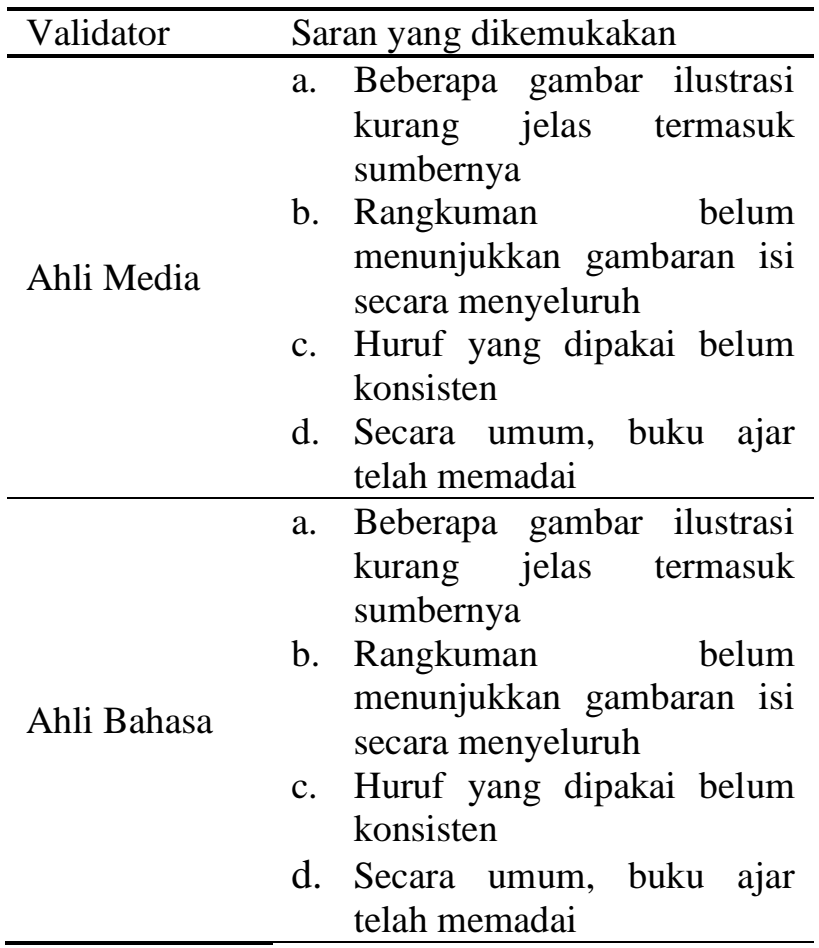


Penilaian oleh validator ahli media dan bahasa menunjukkan bahwa produk bahan ajar (buku ajar dan multimedia interaktif) layak dan siap digunakan untuk pembelajaran pada matakuliah Biologi Sel yang sebenarnya. Berdasarkan aspek kegrafikan/aspek media, buku ajar dan multimedia interaktif telah cukup memenuhi unsu kegrafikan yang baik, misalnya pada penataan gambar dan tulisan, warna tulisan, kelengkapan penyajian, dan sebagainya. Aspek kebahasaan, buku ajar dan multimedia interaktif dinilai cukup komunikatif, dan relevan dengan tingkat perkembangan bahasa mahasiswa.

Unsur kegrafikan dan kebahasaan yang layak dan memadai pada buku ajar dan multimedia diharapkan mampu untuk memotivasi mahasiswa dalam mempelajari isi bahan ajar. Sejalan dengan pendapat Adalikwu, dkk. (2013) yang menyatakan bahwa bahan ajar berperan sebagai fasilitator antara pendidik dengan peserta didik dan mengembangkan motivasi peserta didik selama kegiatan pembelajaran.

Hasil validasi digunakan sebagai acuan untuk melaksanakan tahap revisi terhadap bahan ajar (buku ajar cetak maupun multimedia). Untuk aspek bahasa dan media, proses revisi buku ajar cetak didasarkan pada saran-saran tertulis yang telah diberikan oleh ahli/validator (Tabel 2), karena berdasarkan hasil perhitungan, tiap aspek validasi memiliki kategori layak dengan predikat bagus/sangat bagus. Bagian-bagian buku ajar cetak yang direvisi dipaparkan sebagai berikut.

a. Gambar ilustrasi beserta keterangan yang kurang jelas disebabkan karena kualitas hasil cetak. Buku ajar revisi dicetak ulang dengan menggunakan printer untuk menghasilkan kualitas gambar ilustrasi yang lebih baik.

b. Jenis huruf yang digunakan pada bagian pendahuluan buku ajar (font perpetua) direvisi dan disesuaikan dengan jenis huruf yang digunakan pada bagian inti (font verdana), kecuali jenis huruf untuk judul halaman c. Kompetensi dasar dan indikator kompetensi disesuaikan dengan mengakomodasi tingkat kognitif yang bervariasi, tidak hanya tingkat $\mathrm{C} 2$ seperti versi sebelumnya. Penyesuaian ini didasarkan atas karakteristik materi Biologi Sel.

\section{SIMPULAN DAN SARAN Simpulan}

Berdasarkan tahap penelitian yang telah dilakukan dapat ditarik kesimpulan sebagai berikut.

a. Hasil validasi untuk buku ajar cetak menurut ahli media dan bahasa berada pada kategori layak dengan predikat bagus $(77,34 \%$ untuk aspek media dan 83,33\% untuk aspek kebahasaan).

b. Hasil validasi untuk multimedia interaktif menurut ahli media dan ahli bahasa berada pada kategori layak dengan predikat bagus $(76,46 \%$ untuk aspek media dan $75 \%$ untuk aspek kebahasaan).

c. Revisi yang dilakukan terfokus pada buku ajar cetak, mencakup konsistensi jenis huruf, kualitas gambar ilustrasi beserta keterangannya, serta penyesuaian kompetensi dasar dan indikator kompetensi untuk matakuliah Biologi Sel

\section{Saran}

Saran-saran yang dapat dikemukakan untuk pelaksanaan penelitian selanjutnya antara lain.

a. Perumusan kompetensi dasar dan indikator untuk penulisan buku ajar hendaknya mencakup tingkat kognitif rendah dan tinggi untuk melatih kemampuan kognitif mahasiswa

b. Penyusunan buku ajar harus mampu membangkitkan motivasi mahasiswa untuk membaca dan mempelajarinya, salah satunya dengan memperbaiki kualitas gambar ilustrasi yang digunakan.

c. Jumlah validator ahli untuk aspek materi, media, dan bahasa disarankan 
lebih dari satu orang agar memperleh lebih banyak saran dan masukan bagi perbaikan bahan ajar.

\section{DAFTAR PUSTAKA}

Adalikwu, S.A., dan Iorkpilgh, I.T. (2013). The Influence of Instructional Materials on Academic Performance of Senior Secondary School Students in Chemistry in Cross River State. Global Journal of Educational Research 20 (1): 3945.

Anderson, L.W, dan Krathwoll, D.R. (2001). Kerangka Landasan untuk Pembelajaran, Pengajaran, dan Asesmen. Yogyakarta: Pustaka Belajar.

Alberts, B., Johnson, A., Lewis, J., Raff, M., Roberth, K., and Walter, P.. (2008). Molecular Biology of The Cell Fifth Edition. New York: Garland Science, Taylor \& Francis Group.

Arikunto, Suharsimi. (2008). Dasar-dasar Evaluasi Pendidikan. Jakarta: Bumi Aksara.

Campbell, N.A., Reece, J.B., Urry, L.A., Cain, M.L., Wasserman, S.A., Minorsky, P.V., and Jackson, R.B.. (2009). Biology Eight Edition. San Fransisco: Pearson-Benjamin Cummings.

Susilo, Herawati, Chotimah, Husnul, dan Sari, Yuyun Dwita. (2009). Penelitian Tindakan Kelas sebagai Sarana Pengembangan Keprofesionalan Guru dan Calon Guru. Malang: Bayumedia.

Depdiknas. (2008). Panduan Pengembangan Bahan Ajar. Jakarta:
Direktorat Pembinaan Sekolah Menengah Atas

Direktorat Jenderal Pendidikan Tinggi. (2009). Pedoman Operasional Penilaian Angka Kredit Kenaikan Jabatan Fungsional Dosen ke Lektor Kepala dan Guru Besar. Jakarta: Kemendiknas.

Istanti, A., Prasetyo, T.I., dan Listyorini, D.. (1999). Biologi Sel. Malang: Universitas Negeri Malang.

Muslich, Masnur. (2010). Text Book Writing: Dasar-dasar Pemahaman, Penulisan, dan Pemakaian Buku Teks. Jogjakarta: Ar-Ruzz Media.

Prastowo, Andi. (2012). Panduan Kreatif Membuat Bahan Ajar Inovatif. Jogjakarta: Diva Press.

Program P3AI. (2007). Pedoman Pengembangan Multimedia Interaktif. Bandung: UPI.

Pusat Perbukuan dan Kurikulum. (2008). Instrumen Penilaian Buku Pengayaan Pengetahuan. Jakarta: Badan Penelitian dan Pengembangan Depdikbud.

Snustad, D.P, dan Simmons, M.J.. (2012). Principles of Genetics $6^{\text {th }}$. United States: John Wiley and Sons.

Thiagarajan, S., Semmel, D.S., and Semmel, M.I.. (1974). Instructional Development for Training Teachers of Exceptional Children. Washington: National Center for Improvement of Educational.

Widoyoko, Eko Putro. (2013). Evaluasi Program Pembelajaran: Panduan Praktis bagi Pendidik dan Calon Pendidik. Yogyakarta: Pustaka Pelajar. 